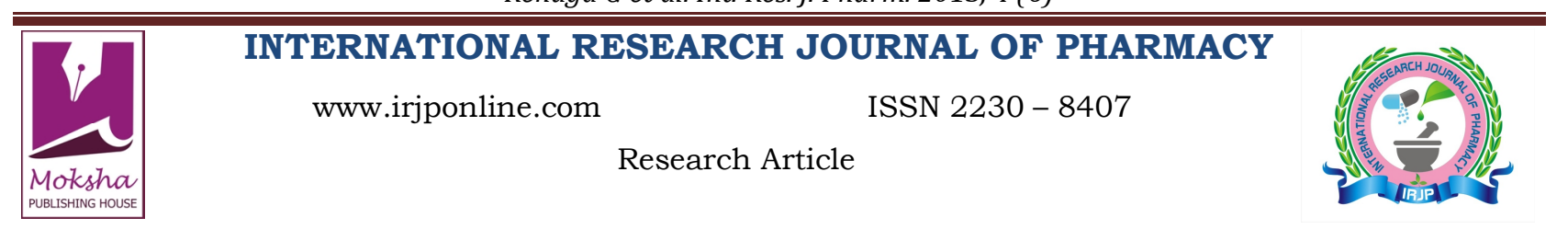

\title{
DETERMINE THE EFFICACY OF CARBOPLATIN WITH VITAMIN C IN DALTON'S LYMPHOMA TUMOR IN MICE MODEL
}

\author{
Renuga $\mathrm{G}^{*}$, Rajesh E and Babu thandapani A. \\ Department of Pharmaceutical Biotechnology, Ultra College of Pharmacy, Madurai, Tamil Nadu, India \\ *Corresponding Author Email: renugabiog@gmail.com
}

Article Received on: 11/03/13 Revised on: 01/04/13 Approved for publication: 17/05/13

DOI: 10.7897/2230-8407.04646

IRJP is an official publication of Moksha Publishing House. Website: www.mokshaph.com

(C) All rights reserved.

\begin{abstract}
Carboplatin, a platinum-containing anticancer drug treatment caused a significant increase in the life span of ascites Dalton's lymphoma tumor bearing mice. However, as compared to carboplatin alone, combination treatment with vitamin $\mathrm{C}$ plus carboplatin resulted in better therapeutic efficacy against Dalton's lymphoma tumor.To investigate difference in resistance mechanism to diamine (cyclobutane-1,1- dicarboxylato (2-)-O,O') platinum (CBDCA) and changes in antioxidant levels in liver tissues in relation to different stages of Dalton's lymphoma tumor growth and the following carboplatin treatment. The reduction in intracellular accumulation of CBDCA is thought to be an important factor indicating that CBDCA resistant in DLA cell are mutually cross-resistant. Glutathione level increased in liver of tumor bearing compared to normal mice. Intracellular accumulation of platinum found to be higher in tissue, after carboplatin treatment the platinum accumulation were significantly decreased. Antioxidant defense systems such as superoxide dismutase, glutathione peroxidase glutathione reductase activities and Glutathione-S-transferase activity were determined in tissues of carboplatin treatment at different stages of Dalton's lymphoma tumor growth. Resistance mechanism based on reduction of intracellular drug accumulations and increased activity of GST also depend the level of antioxidant enzymes, GST activities are playing significant role in development of resistance in the presences of tumor under various newly developed platinum derivative factor. Anticancer drugs kill susceptible cells through induction of apoptosis. Alteration of apoptotic pathways in drug resistant tumor cells leading to apoptosis deficiency might represent a potent mechanism conferring drug resistance.
\end{abstract}

Keywords: Anticancer drug, Carboplatin, Dalton's lymphoma tumor, Glutathione-S-transferase, Glutathione, Resistance.

\section{INTRODUCTION}

Chemotherapy is the treatment of cancer with drugs (anticancer) that can destroy cancer cells. It interferes with cell division in various possible ways with the duplication of DNA or the separation of newly formed chromosomes most forms of Chemotherapy target all rapidly dividing cells and are not specific for cancer cells ${ }^{1}$. The platinum anti tumor agents are unique, coordination complexes and the parent compound of this class Cis- diammine-dichloroplatinum(11) (Cisplatin), contributes to the curative treatment of various cancers such as testicular teratoma, ovarian, head, neck, bladder, cervical and lung cancers. The compound is also highly toxic with a list of side effects including renal damage, nausea, vomiting, myelo- suppression, neurotoxicity and nephrotoxicity ${ }^{2}$. The platinum analogues are the most active chemotherapy agents for the treatment of ovarian cancer. Even though majority of the patients eventually becomes refractory to the treatment and resistance develops which limits the use of these drugs ${ }^{3}$.

Carboplatin is a second generation platinum containing anticancer drug. It is currently being used in the clinic against lung cancer, ovarian, head and neck cancers ${ }^{4}$. The identification of doses escalation of carboplatin is an important factor in achieving optimal antineoplastic effects ${ }^{5}$. Carboplatin displays less toxicity than its analog cisplatin, but antitumor activity is equivalent to that of cisplatin ${ }^{6}$. Single high does or repeated doses of carboplatin chemotherapy have been shown to produce ototoxicity as a side effect in cancer patients ${ }^{7}$. Carboplatin induced ototoxicity has also been demonstrated in experimental animals such as guinea pigs and chinchillas ${ }^{8}$. The antitumor action of carboplatin is mediated by alkylation of DNA followed by killing of the cancerous cells ${ }^{9}$. Biochemical studies have been succeeded in identifying conclusively the basis of resistance in any type of cell selected with carboplatin. GSH controls the onset of tumor cells proliferation by regulating protein kinase $\mathrm{C}$ activity and intracellular $\mathrm{pH}$. A decrease in the rate of cancer cell proliferations has also been correlated with a decrease in GSH level in tumor cell. Thus the variation of GSH concentration in the host may reflect alterations in the antioxidant machinery accompanied by change in the rate of proliferation of Dalton's Lymphoma cells and other tissues with tumor growth in the host may reflect alterations in the antioxidant machinery accompanied by change in the rate of proliferation of Dalton's lymphoma cells in the host ${ }^{10}$.

GST inducers are generally considered as protect on compounds against cancer, acting as blocking agents ${ }^{11}$. An increase in hepatic GST activity may induce a general protection state, leading to an inhibition in cancer initiation in the liver as well as in other sites such as ovarian tissue ${ }^{12}$. Therefore, it was interest to determine GSH levels in various tissues during ascites Dalton's lymphoma growth in vivo and carboplatin treatment. Platinum uptake and glutathione-Stransferase (GST) activity were also measured in various tissues collected from mice under different experimental conditions in an attempt to identify the mechanism of GSH changes and its significance in carboplatin- mediated cancer chemotherapy.Present study was designed in order to evaluate the dose response of carboplatin induced changes in the endogenous antioxidant defense system such as GSH level, antioxidant enzyme activities of superoxide dismutase (SOD), glutathione peroxidase, glutathione reductase and glutathione-S-transferase (GST) in the tumor bearing mice.

\section{MATERIALS AND METHODS}

\section{Experimental animal maintenance}

Inbred Swiss Albino mice (20-25g) were maintained in the Laboratory Animal Feeds, (Bangalore) and albino mice were maintained in the laboratory with free access to commercially available food pellets and water. For each experimental group 4-5 mice aged 10-12 weeks (25-30g) were used. The animals 
were housed in spacious polypropylene cages bedded with rice husk. The animal room was well ventilated and maintained under standard experimental conditions [Temperature $27^{\circ} \mathrm{C}$ and 12 hours light/dark cycle] throughout the experimental period. Animal experiments were carried out following the guidelines of the animal ethics committee of the Institute. Dalton's Lymphoma ascites was obtained from Amala Cancer Institute, Trisshur, Kerala Dt., India.

\section{Tumour Induction}

Ascites Dalton's lymphoma tumor was maintained in vivo by intraperitoneal (ip) transplantation of $1 \times 10^{6}$ tumor cells per animal ( 0.25 volumes, in phosphate - buffered saline, PBS). PBS was prepared by adding $0.15 \mathrm{M} \mathrm{NaCl}$ to $0.01 \mathrm{M}$ sodium phosphate buffer, $\mathrm{pH}$ 7.4. Since tumor- transplanted animals usually survived for 18-20 days, and were allowed to grow with tumor. The treatment was started from the $2^{\text {nd }}$ and $11^{\text {th }}$ day for the experimental design and 5.10 and 15 days were considered to be the initial, middle and later stages of tumor growth, respectively.

\section{Experimental scheduled given below}

Experimental animals were divided into three treatment groups involving 60 mice of 4 batches containing 15 mice each and injected as follows:

Batch 1 animals received normal saline and were used as control (saline $10 \mathrm{ml} / \mathrm{kg}$ of body wt intraperitoneal (i.p) injection $(n=5)$;

Batch 2 animals were induced cancer with Dalton's lymphoma ascites (Amala cancer Institute Trissur, Kerala). Ascites Dalton's lymphoma tumor was maintained in vivo by intraperitoneal (ip) transplantation of $1 \times 10^{6}$ tumor cells per animal ( 0.25 volume, in

Phosphate-buffered Saline, PBS). PBS was prepared by adding $0.15 \mathrm{M} \mathrm{NaCl}$ to $0.01 \mathrm{M}$

Sodium phosphate-buffered $\mathrm{pH} 7.4$ animals were allowed to grow with tumor.Treatment was started from the $2^{\text {nd }}$ and $11^{\text {th }}$ day for the batch 2 served as normal.

Batch 3 animals received a single dose of drug carboplatin was administrated to tumor -bearing mice on the $8^{\text {th }}$ day of tumor growth (maintained as experimental group 1)(Preparation of doses: Carboplatin Dose $(10 \mathrm{mg} / \mathrm{ml}$ was dissolved in 5\% dextrose in water and use immediately).

Batch 4 animals received a combination dose of vitamin $\mathrm{C}$ $500 \mu \mathrm{g} / \mathrm{kg}$ body wt,i.p) was administered to tumor bearing mice before $8 \mathrm{~h}$ of sub- therapeutic dose of carboplatin $(5$ $\mathrm{mg} / \mathrm{kg}$ body wt,i.p) administration (maintained as experimental group 2). Treatment was started $24 \mathrm{hrs}$ after the tumor inoculation and continued for 16 days, body weight of animals were noted daily in all groups during treatment period. On the 17 th day of mice in all the groups mice were subjected for experimental studies, fasting blood samples were collected from 3 animals from each batch and the rest of the animal were kept to check the survival time of DLA bearing mice, subsequently animals were sacrificed by anesthesia and organs tissue were isolated (liver, blood, ascites tumor) frozen in liquid nitrogen and stored at $-80^{\circ} \mathrm{C}$ until biochemical analysis could be completed. If any death, of the animals in different groups were recorded daily and the survival pattern of the animals were determined for different group. The parameters such as survival time, packed cell volume, body weight, haemotological parameters like RBC count, WBC count, were studied during the period of experiment.
Host Survival: The mortality of animals dying was noted and the Percentage increase in life span (\%ILS) was calculated from the formula $[(\mathrm{T}-\mathrm{C} / \mathrm{C})] \times 100$

Where, $\mathrm{T}=$ Number of days treated animal survived, $\mathrm{C}=$ Number of days control animal survived.

The weight of the animals in all the groups after treatment was noted and the mean body weight for every group were calculated. The percentage increase /decrease in body weight in comparison with the control were calculated thereafter.

\section{Carboplatin treatment and tissue collection:}

On the $17^{\text {th }}$ day of tumor growth, tumor-bearing mice were killed by cervical dislocation, and liver, blood, ascites tumor, were collected. Bone marrow cells were prepared from humerus and femur by flushing in PBS with a hypodermic syringe and by centrifugation (3000 g, $10 \mathrm{~min})$ to collect. Ascites tumor centrifuged $(3000 \mathrm{~g}, 10 \mathrm{~min})$ to separate the Dalton's lymphoma cell pellet and the ascites supernatant. According to the dose and treatment schedule used a single dose of Carboplatin (10mg/Kg body weight, ip) was administered to tumor -bearing mice on the $11^{\text {th }}$ day post tumor transplantation of treated tissues were collected and used for further experiment the normal (untreated, tumorbearing group1) mice and uses as the normal and the tissues of control (untreated tumor-bearing group1) mice injected with normal saline only and uses as the normal counterpart of Dalton's lymphoma cells in Platinum determinations. Haematological parameters like RBC counts, WBC counts ${ }^{13}$, haemoglobin ${ }^{14}$ and Estimation of Packed cell volume (PCV) of the ascitic fluid was collected centrifuged at 1000 rpm for $10 \mathrm{~min}$ and the other part of the ascitic fluid were separated by centrifugation and stained with trypan blue $(0.4 \%$ in normal saline). The viable and nonviable cells were counted using a Neubauer chamber (hemocytometer).

Measure of Viability: This procedure can be performed along with the cell counting procedure but cell density may require adjustment in order to obtain approximately $10^{6}$ cells per milliliter. Mix 1 drop of trypan blue with one drop of the cell suspension and allow 1 - 2 minutes for absorption. Prepare haemocytometer and load chambers as described in "Cell Quantitation". Count both the total number of cells and the number of stained (dark) cells

Calculation: percent viability $=($ Total cell counted - Stained cells) X 100 / Total cells counted

The ascites tumor cells are obtained by aspirate with Phosphate buffer saline in the peritoneal Cavity of DLA bearing mice. The cells were then mixed with $0.4 \%$ Trypan blue in the ratio of $1: 1$ and the cells were counted using the Haemocytometer. (Live cells do not take stain whereas the dead cells get stained)

\section{Determination of platinum uptake by Dalton's lymphoma} cells:

The cells were washed with PBS thrice, (Phosphate Buffer Saline) collected and stored at $-20^{\circ} \mathrm{C}$ until use. Intracellular platinum accumulation was measured by a modification of the method of the Dalton's lymphoma cell pellet were also processed for platinum uptake analysis. The cell pellet $(0.5 \mathrm{~g})$ was digested with $5.0 \mathrm{ml}$ nitric acid and a few drops of hydrogen peroxide in a clean conical flask with gentle heating to near dryness. Perchloric acid $(5.0 \mathrm{ml})$ was added to the digests and again heated to near dryness to remove excess nitric acid. This last stage was repeated until a clear solution resulted. The digests were finally dissolved in $5 \mathrm{ml}$ of $5 \%$ 
nitric acid (distilled water and nitric acid at the ratio of 95:5ml), and the filtrate was stored in polypropylene bottles for platinum analysis using Atomic Absorption Spectrophotometry ${ }^{15}$. The filtrate was stored in polypropylene bottles for Platinum analysis using a plasma lab ICP-OES emission spectrometer operated at 700 volts PMT and 214,438 nm of wave length after calibrating the instrument with the appropriate standard solutions. The intracellular platinum content was normalized to the cellular protein content estimated by using ${ }^{16}$. Enzyme assays: SOD activity was determined at room temperature according to the method of ${ }^{17}$. The assay of Glutathione peroxides was determined by the method of ${ }^{18}$. Glutathione reductase (GR) activity was determined by the method of ${ }^{19}$. Glutathione was estimated in tissues by the method of ${ }^{20}$. GST activity was measured in the supernatant fractions according to the method of ${ }^{21}$.

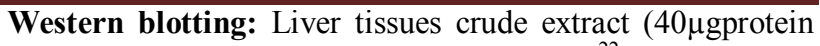
per lane) were analyzed by $15 \%$ SDS-PAGE ${ }^{22}$. Proteins were transferred electrophoretically to nitrocellulose filters (for $3 \mathrm{~h}$ at $1 \mathrm{~A}$ ) using an immunoblot transfer apparatus. After transfer, the nitrocellulose was incubated for $1 \mathrm{~h}$ at room temperature in $3 \%(\mathrm{w} / \mathrm{v}) \mathrm{BSA}$ in Tris-buffered saline (TBS; $500 \mathrm{mM} \mathrm{NaCl}$ and $20 \mathrm{mM}$ Tris- $\mathrm{HCl} \mathrm{pH} 7.5)$ to block non specific binding. The blot was incubated overnight at $4^{\circ} \mathrm{C}$ with $3 \%(w / v) ~ B S A$ in TBS containing antiserum at a dilution of 1:500. After three $15 \mathrm{~min}$ washes with TBS containing $0.1 \%$ BSA and $0.2 \%$ Nonidet $\mathrm{P} 40$, the blot was incubated for $1 \mathrm{~h}$ at room temperature with peroxidase- conjugated goat anti (mouse immunoglobulin) diluted at $1: 1000$ in $3 \%$ BSA in TBS. The blot was again washed three times with TBS containing $0.1 \%$ BSA and $0.2 \%$ Nonidet P40. Antibodies were visualized using a chem.-illuminescence detection system.

Table 1: Percentage of Tumor inhibition

\begin{tabular}{|c|c|c|c|}
\hline Parameters & Tumor induced as normal & Carboplatin drug treated & Carboplatin plus vitamin treated \\
\hline & $13.54 \pm 0.62$ & $8.32 \pm 0.31$ & $6.42 \pm 0.19$ \\
\hline Packed volume & $4.76 \pm 0.21$ & $3.09 \pm 0.30$ & $2.04 \pm 0.23$ \\
\hline \%Tumor inhibitions & - & $35.09 \%$ & $57.14 \%$ \\
\hline
\end{tabular}

The data illustrate the results of an experimental set up that was repeated three times. Mean \pm SD of 5 Experiments.

Table 2: Haematalogical study on DLA mice after treatment

\begin{tabular}{|c|c|c|c|c|}
\hline Parameters & Control mice & Tumor induced as normal & Carboplatin drug treated & Carboplatin plus vitamin treated \\
\hline WBC $\left(10^{3}\right.$ cell $\left./ \mathrm{mm}^{3}\right)$ & $19.02 \pm 0.15$ & $27.37 \pm 0.19$ & $24.15 \pm 0.30$ & $20.36 \pm 0.12$ \\
\hline RBC $\left(10^{6}\right.$ cells $\left./ \mathrm{mm}^{3}\right)$ & $4.52 \pm 0.20$ & $2.81 \pm 0.23$ & $2.5 \pm 0.18$ & $3.12 \pm 0.12$ \\
\hline Haemoglobin $(\mathrm{g} \mathrm{\% )}$ & $14.0 \pm 0.14$ & $9.8 \pm 0.54$ & $11.3 \pm 0.18$ & $12.6 \pm 0.17$ \\
\hline
\end{tabular}

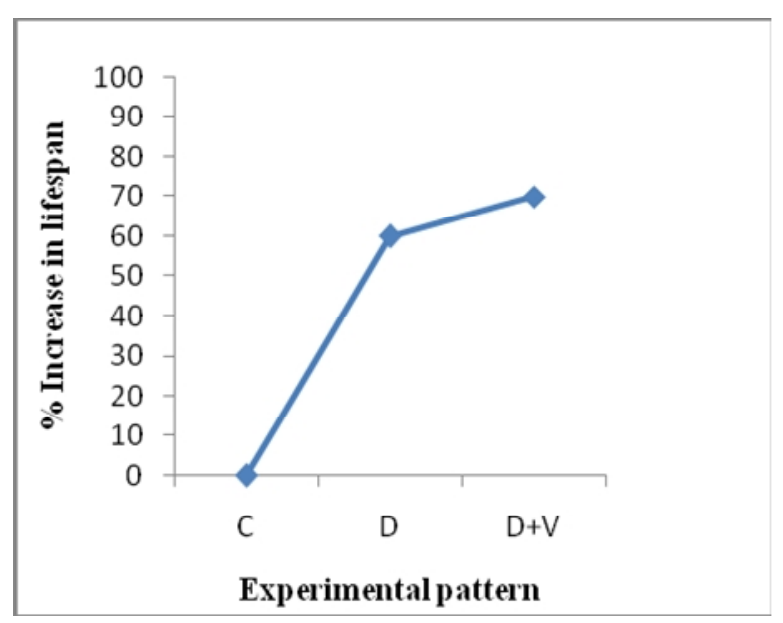

Figure 1: Percentage increase in Life span

Animal survival was calculated and expressed as Percentage increase in life span (\%ILS). Experimental pattern represents as C- Control; D- Carboplatin drug; D+ V- Carboplatin drug plus Vitamin. Each values were average of 5 animals. 


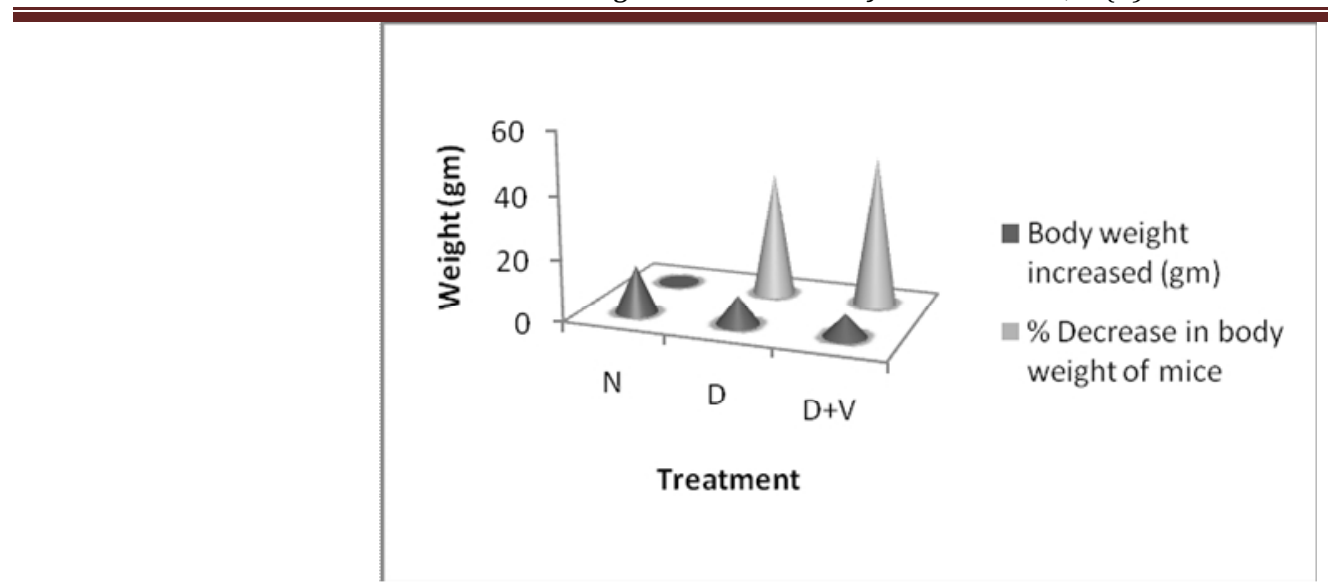

Figure 2: Differences in Body weight of mice on treatment

Body weights of tumor animals were determined individually during treatment and the differences were calculated from three replicates of each group. In treatment pattern; N - Indicated tumor induced animal (Maintained as Normal group); D - Indicated single dose of drug carboplatin was administrated to tumor bearing mice on the $8^{\text {th }}$ day of tumor growth (maintained as treated group 1); $\mathbf{D}+\mathbf{V}$-Indicated animals received combination dose of carboplatin drug plus vitamin $\mathbf{C}$ was administered to tumor bearing mice (maintained as treated group 2). Body weights of animals were given in body wt increased (grams) and the body wt difference represents in \% decrease in body wt of animal.

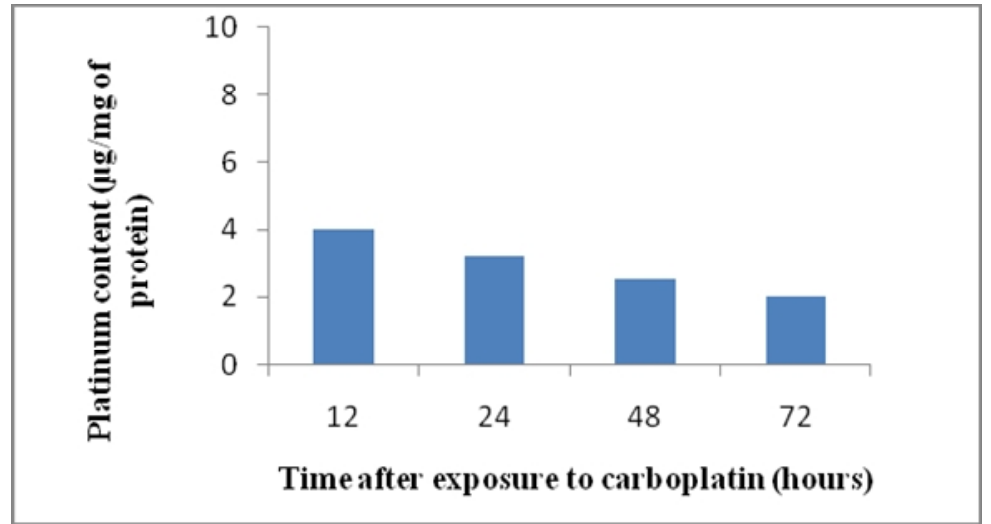

Figure 3: Intracellular Platinum accumulation after carboplatin treatment

Intracellular Platinum accumulation after different time exposure to the respective drugs at various concentrations in tumor induced mice. $\mathrm{X}$ - indicated time intervals such as $12 \mathrm{~h}, 24 \mathrm{~h}, 48 \mathrm{~h}$ and $72 \mathrm{~h}$.

Y-indicates accumulated contents of platinum expressed as $\mu \mathrm{g} / \mathrm{mg}$ of protein of homogenized live tissues.

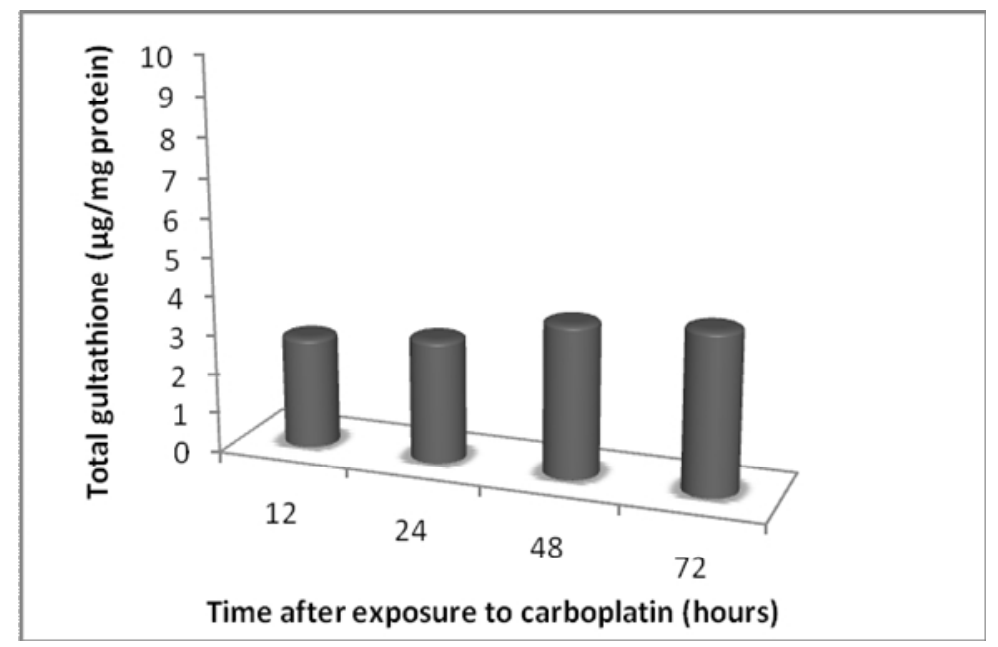

Figure 4: Estimation of Glutathione in DLA mice after trearment

Glutathione contents in DLA bearing mice after trearment of carboplatin at different time exposure to drugs at various concentrations in tumor induced mice. $\mathrm{X}$-indicated time intervals such as $12 \mathrm{~h}, 24 \mathrm{~h}, 48 \mathrm{~h}$ and $72 \mathrm{~h}$. Y-indicates accumulated contents of total glutathione expressed as $\mu \mathrm{g} / \mathrm{mg}$ of protein of homogenized live tissues. 


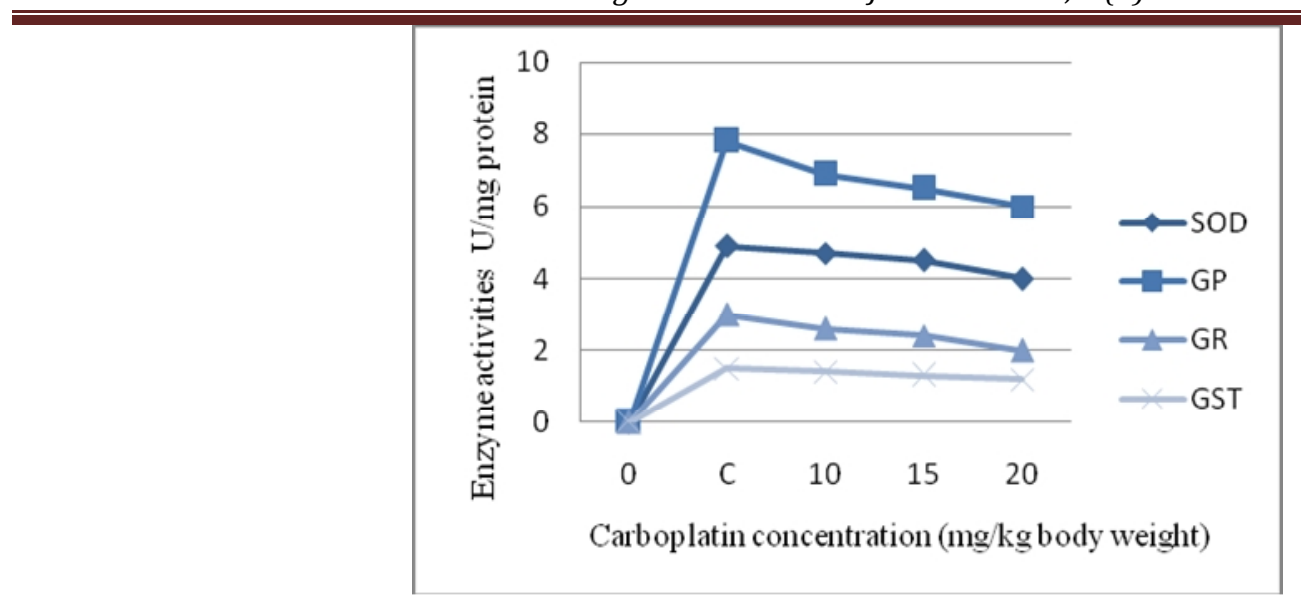

Figure 5: Measurement of antioxidant enzymes activities

Enzyme activities are expressed as U/mg protein. Each value was represents with 5 experimental animals. Enzymes were measured under various doses of carboplatin treatments in tumor induced mice. SOD- Superoxide dismutase; GP -Glutathione peroxidase; GR- Glutathione reductase; GST- Glutathione -S -transferase.

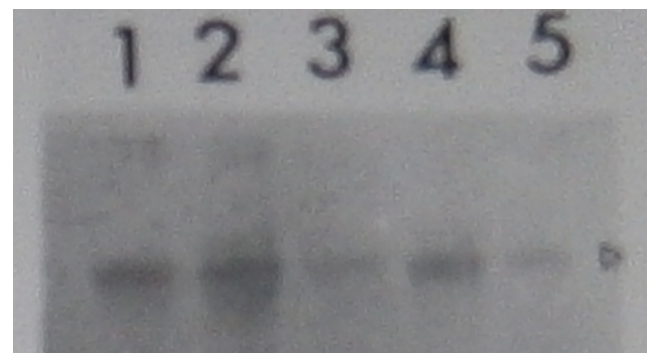

Figure 6 : Western blotting of GST

Lane 1. GST molecular weight markers; Lane 2 . GST specified protein from normal mice;

Lane 3. GST specified protein from tumor induced; Lane 4. GST specified protein from tumor treated with carboplain;

Lane 5. GST specified protein from tumor treated with carboplain plus vitamin $\mathrm{C}$.

\section{RESULTS}

Animals were injected with DLA tumor cells and treated with different combinations of drug carboplatin maintained the experimental setup then subjected for all experimental studies such as host survival and bodyweight differences, haematological parameters. Figure 1 revealed the result of percentage increased in life span (\% ILS). The results were as expected that carboplatin and combination of carboplatin drug with vitamin have shown sufficient cytotoxicity with trypan blue dye exclusion techniques as shown in Table 1. The efficiency of the drug administration was studied and the results shown that the Carboplatin plus vitamin treated group was found to be more effective and in exhibiting the antitumor activity against DLA cells. The body weight differences after treatment was calculated by observing the weight gain on $17^{\text {th }}$ day after cancer induction. Whereas, the tumor inhibition was calculated by estimating the packed cell volume of DLA, treated groups showed better tumor inhibition (Table 1).

The changes in the weight of mice treated with graded doses of carboplatin are depicted Figure 2. Carboplatin decreased the body weight of mice, in both the treated groups of (treatment after post infection) carboplatin drug treated (Group1) and carboplatin plus vitamin treated (Group 2) showed $\%$ decrease in body weight $41 \%$ and $53 \%$ respectively. The significant decrease in body weight was observed at the combination dose of carboplatin plus vitamin treatment. A significant weight loss 5 days following higher doses of carboplatin administration in mice may be due to enhanced catabolism, loss of body fluid due to gastrointestinal toxicity and reduction in food and water intake. The intracellular platinum accumulations in cells vary according to their exposed various condition (Figure 3 ). The reduction in intracellular accumulation of CBDCA is thought to be an important factor indicating that CBDCA resistant cells are mutually cross-resistant. The reduction of intracellular platinum accumulation has observed when the cells were exposed to combination of CBDCA with vitamin. It is therefore likely that the reduction in intracellular drug accumulation is not the main mechanism of resistance to tumors cells.GSH levels during tumor growth and carboplatin treatment, GSH levels had changed much in liver at different stages of tumor growth (Figure 4). A $60 \%$ increase in GSH content was observed in Dalton's lymphoma cells treated in combination therapy of carboplatin with vitamin $\mathrm{C}$. There was no significant differences were determined between the tumor bearing and control groups in the analysis of antioxidant parameters measured in liver tissue (Figure 5). GST activity was decreased, suggesting that the GSH detoxification mechanism may be participate as a resistance mechanism when western blot analysis (Figure 6) revealed the data presented here suggest that changes in GST levels in Dalton's lymphoma cells and other tissues during tumor growth and after carboplatin treatment could be an important factor contributing to tumor regression and carboplatinmediated anticancer activity.

\section{DISCUSSION}

Maximum GSH concentration was observed by about the $7^{\text {th }}$ day of tumor growth, followed by a significant decrease on the $14^{\text {th }}$ day of tumor growth, which was correlated with a decrease in cell proliferation and in the rate of GSH 
synthesis. Cancer cell generate large amounts of hydrogen peroxide which may contribute to their ability to mutate and damage normal tissues, and facilitate tumor growth and invasion. It has been suggested that persistent oxidative stress in tumor cell could partly explain some important characteristics of cancer, such as activated proto-oncogenes, genomic instability, drug resistance, invasion and metastasis, and the resistance of many cells against oxidative stress is often associated with high intracellular levels of GSH. The observed increase of GSH mainly in tumor cells suggests its involvement in facilitating the proliferation and metabolism of tumor cells in the host and agrees with mitogenic stimulation and that GSH controls the onset of tumor cell proliferation by regulating protein kinase $\mathrm{C}$ activity and intracellular $\mathrm{pH}$. As GSH is known to play a role in detoxifying many reactive metabolites, its increased levels in Dalton"s lymphoma cells and tissues of tumor -bearing mice could also represent a protective mechanism in response to various toxic radicals.

The enhanced drug uptake by Dalton's lymphoma cells under the condition of reduced GSH levels and GST activity in Dalton's lymphoma cells should be an important determining factor in the cytotoxic effects of carboplatin against murine ascites Dalton's lymphoma. The elevated drug uptake by the tumor cell under the condition of increased glutathione concentration and GST activity after treatment could be an important contributory factor to carboplatin's anticancer activity leading to tumor regression. GST which belongs to a gene family of phase 11 detoxification enzyme are involved in the conjugation of a wide range of xenobiotics to the endogenous nucleophile glutathione.GST represents an integral part of the detoxification system and protects cells against oxidative and chemical -induced toxicity and stress by catalyzing the S-conjugation between the thiol group of GSH and the electrophilic moiety of toxic substrates including carboplatin. The increase in GST activity identified in mice model, there was a specific induction in GST expression which paralleled the increase in total GST activity. Firstly, a reduction of intracellular CBDCA accumulation occurs in the majority of resistant cells. Secondly, increases in intracellular glutathione (GSH) concentration and glutathione S-transferase (GST) activity have been reported. GSH and GST are believed to play important roles in drug detoxification.

\section{CONCLUSION}

Carboplatin was one of the most potent antitumor agents known displaying clinical activity against a wide variety of tumors. When Carboplatin enters the cells, it is potentially vulnerable to cytoplasmic inactivation by these and other intracellular components. Elevated levels of GST are associated with increased resistance to apoptosis initiated by a variety of stimuli and it was plausible that GSTs serve two distinct roles in the development of drug resistance via direct detoxification as well as acting as an inhibitor of the MAP kinase pathway. The use of a subtherapeutic dose $(10 \mathrm{mg} / \mathrm{kg}$ body weight) of carboplatin in combination with vitamin $\mathrm{C}$ has been suggested to have better therapeutic efficacy than carboplatin alone, and decreased side effects in the host

\section{REFERENCES}

1. Garbe C. Chemotherapy and Chemo immuno therapy in discriminated malignant melanoma. Melanoma Research 1993; 3: 291-299. PMid:7693093
2. Rybak LP, Husain K,Whitworth C, Somani SM. Dose dependent protection by lipoic acid against cisplatin induced ototoxicity in rats: antioxidant defense system.ToxicolSci1999; 47: 195-202. http://dx.doi .org/10.1093/toxsci/47.2.195 PMid:10220857

3. Heike Helmbach, Monika A, Kerm Evelyn R, Kristina Renz, Christina Kissel, Brigitte, Geschwendt and Drik Scandendrof. Drug resistance towards Etoposide and cisplatin in human melanoma cell is associated with Drug-Dependent apotosis deficiency. J Invest Dermatol 2002; 118: 923-932.http://dx.doi.org/10.1046/j.1523-1747.2002.01786.x PMid: 12060385

4. Ettinger DS. The role of carboplatin in the treatment of small cell lung cancer. Oncology 1998; 12: 36-43 PMid:9516610

5. Bohm S, Oriana S, Spattig, DiRe F, Breasciani G, Pirovano C, Grosso I, Martini C, Caraceni A, Pilotti S, Zunini F. Dose intensification of platinum compounds with glutathione protection as induction chemotherapy for advanced ovarian carcinoma. Oncology 1999; 57: 115-120. http://dx.doi.org/10.1159/000012017 PMid: 10461057

6. Kennedy IC, Fitzharris BM, Colls BM, Atkinson CH. Carboplatin is ototoxicity. Cancer Chemotherapy Pharmacol 1990; 2: 232-234. http:// dx.doi.org/10.1007/BF02897206

7. Cavaletti G, Boglium G, Zincone A, Marzorati L, Metzi P, Frattola L, Marzola M, Bonazzi C, Cantu MG, Chiari S, Galli A, bregni M, Gianni M. Neuro and ototoxicity of high dose carboplatin treatment in poor prognosis ovarian cancer patients. Anticancer Res 1998; 18: 3797- 3802. PMid:9854499

8. Maldoon LL, Pagel MA, Kroll RA, Brummett RE, Doolittle ND, Zuhowski EG, Egorin MJ, Neuwett EA. Delayed administration of sodium thiosulfate in animal models reduces platinum ototoxicity without reduction of anti tumor activity. Clin.Cancer.Res. 2000; 6: 309315 .

9. Taudy M, SykaJ, Popelar J, Ulehlova L. Carboplatin and ciapatin ototoxicity in guinea pigs. Audiology 1992; 31: 293-299 http://dx.doi. org/10.3109/00206099209072917 PMid:1449432

10. Estrela JM, Obrador E, Navarro J, Lasso De KaVeger Mc, Pellicer JA. Elimination of Ehrlich tumors by ATP induced growth inhibition.Glutathione depletion and X-rays. Nature medicine 1995: 1: 84-88. http://dx.doi.org/10.1038/nm0195-84 PMid:7584960

11. Morse MA, Stoner GD. Cancer chemoprevention: Principles and Prospects. Carcinogenesis 1993; 14: 1737-1746. http://dx.doi.org/ 10.1093/carcin/14.9.1737 PMid:8403193

12. Hayes JD, Mclellan LI. Glutathione and Glutathione dependent enzymes represent a Co- ordinary regulated defense against Oxidative stress. Free Rad Res 1999; 31:273-300. http://dx.doi.org/10.1080/ 10715769900300851 PMid: 10517533

13. Sokoll LJ. Biomarkers for cancer diagnostics. 4th ed, Clinical oncology. Philadelphia churchill Livingstone: Elsevier 2008:279.

14. Danyelle M, Townsend J, Kenneth D. Transitional cell cancer of the renal pelvis and urethra treatment (PDQ). National cancer Institute.[Serial on the internet] Accessed Jan. 13,2010. Availablefrom:http://www.cancer.gov/cancertopics/pdq/treatment/transit ionalcell/patient/.

15. Pera MF, Harder HC. Analysis for platinum in biological material by flameless atomic absorption sp mercapturic acid formation. J Biol Chem 1974; 249:7130-7139.

16. Lowry OH, Rosebrough NJ, Farr A,L Randal RJ. Protein measurement with the Folin Phenol reagent. JBiolChem1951; 193:256-275.

17. Misra HP, FridovichI. The role of superoxide anion in the autooxidation of the epinephrine and a sample assay for superoxide dismutase. J.Biol.Chem.1972; 247: 3170- 3175. PMid:4623845

18. Flohe L, Gunzler W. Assay of glutathione peroxide.Methods. Enzymol 1984; 105:114-117. http://dx.doi.org/10.1016/S0076-6879(84)05015-1

19. Carlberg I, Mannervik B. Glutathione reductase. Methods enzymol 1985; 113: 484 - 490. http://dx.doi.org/10.1016/S0076-6879(85)13062-4

20. Sedlak J, Linday RH. Estimation of total protein bound and non protein sulhydryl group in tissue with Ellman's reagents. Analytical Biochemistry 1968; 25: 192-205. http://dx.doi.org/10.1016/00032697(68)90092-4

21. Habig WH, Pabst MJ, Jakoby WB. Glutathione S-transferases. The first enzymatic step in mercapturic acid formation. J Biol Chem 1974; 249: 7130-7139. PMid: 4436300

22. Laemmli Uk. Cleavage of structural proteins during the assembly of the head of bacteriophage T4. Nature1970; 227: 680-85. http://dx .doi.org/10.1038/227680a0

Cite this article as:

Renuga G, Rajesh E and Babu thandapani A. Determine the efficacy of Carboplatin with vitamin $\mathrm{C}$ in Dalton's lymphoma tumor in mice model. Int. Res. J. Pharm. 2013; 4(6):205-210 